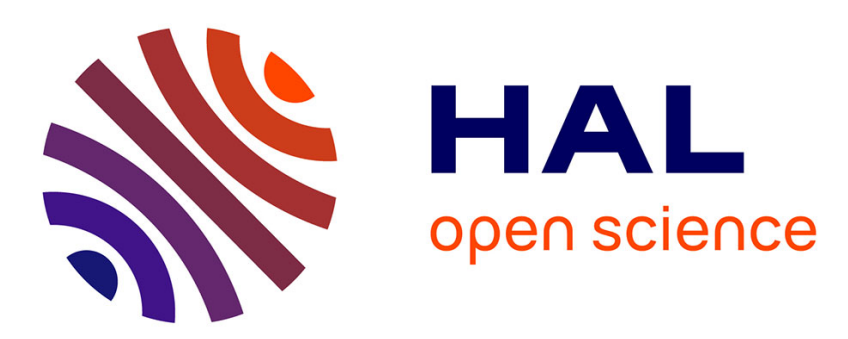

\title{
Short-term physiological responses to a severe acid stress in three macroinvertebrate species: A comparative study
}

V. Felten, F. Guerold

\section{To cite this version:}

V. Felten, F. Guerold. Short-term physiological responses to a severe acid stress in three macroinvertebrate species: A comparative study. Chemosphere, 2006, 63, p. 1427 - p. 1435. 10.1016/j.chemosphere.2005.10.003 . hal-00452244

HAL Id: hal-00452244

https://hal.science/hal-00452244

Submitted on 1 Feb 2010

HAL is a multi-disciplinary open access archive for the deposit and dissemination of scientific research documents, whether they are published or not. The documents may come from teaching and research institutions in France or abroad, or from public or private research centers.
L'archive ouverte pluridisciplinaire HAL, est destinée au dépôt et à la diffusion de documents scientifiques de niveau recherche, publiés ou non, émanant des établissements d'enseignement et de recherche français ou étrangers, des laboratoires publics ou privés. 
Author-produced version of the article published in Chemosphere 2006, 63, 1427-1435.

The original publication is available at http://www.sciencedirect.com/ doi : 10.1016/j.chemosphere.2005.10.003 
1 Short-term physiological responses to a severe acid stress in three

\section{2 macroinvertebrate species: a comparative study.}

3 V. Felten ${ }^{a}$ and F. Guérold ${ }^{b, c^{*}}$.

4

5 a Laboratoire d'écotoxicologie, CEMAGREF, 3 bis quai Chauvau, 69336 Lyon, CP 220, 6 Cedex 09, France.

$7 \quad{ }^{\mathrm{b}}$ Laboratoire Biodiversité et Fonctionnement des Ecosystèmes, Université de Metz, Campus 8 Bridoux, Rue du Général Delestraint, 57070 Metz, France.

$9 \quad{ }^{\mathrm{c}}$ Laboratoire Ecotoxicité et Santé Environnementale, CNRS UMR 7146, Université Paul

10 Verlaine - Metz Rue du Général Délestraint, 57070 Metz, France

\section{Abstract}

The present study focuses on the sensitivity among freshwater invertebrate species to acidic stress. Three common macroinvertebrate species in the Vosges Mountains (North-Estern France), Gammarus fossarum (Amphipoda), Hydropsyche pellucidula (Trichoptera) and Dinocras cephatotes (Plecoptera) were exposed for 24, 72 and 120 hours to natural acidified water $\left(\mathrm{pH}=4.73 \pm 0.08,\left[\mathrm{Ca}^{2+}\right]=39.1 \pm 0.6 \mu \mathrm{mol} . \mathrm{L}^{-1},\left[\mathrm{Al}_{\mathrm{tot}}\right]=28.4 \pm 1 \mu \mathrm{mol} . \mathrm{L}^{-1}\right)$. Short-term exposure to acid stress caused significant decreases both in survival rate and haemolymph ions $\left(\left[\mathrm{Cl}^{-}\right]\right.$and $\left.\left[\mathrm{Na}^{+}\right]\right)$. The relative sensitivity to a natural acidic stress slightly differed among the species and was in the following order: G. fossarum, as the most sensitive, then $H$.

21 pellucidula and D. cephalotes. Results of this study confirm the interest of in situ tests to assess the toxicity of short-term acid exposure. Finally, our results reinforce the hypothesis that transient acidification can offset the recovery of sensitive species of macroinvertebrates

24 in streams chemically recovering from acidification either through liming or declining 25 deposition. 
Keywords: Acidification, Macroinvertebrate, Ion loss, Survival, Acid-sensitivity.

INTRODUCTION

Acidification of freshwater ecosystems related to anthropogenic emissions of $\mathrm{SO}_{2}$ and $\mathrm{NO}_{\mathrm{X}}$

has been one of the most striking ecological problems throughout the northern hemisphere during the 20th century. National and international legislation in the 1980s and 1990s aimed at reducing the emissions of acidifying pollutants (e.g. Clean Air Act in the USA and the Convention on Long-Range Transboundary Air Pollution in Europe) have led to the decline in acidic depositions across wide areas of Europe and North America (Stoddard et al., 1999, Lawrence et al., 2000, Evans et al., 2001, Likens et al., 2001, Folster and Wilander, 2002).

Consequently, it has been assumed that the 'acidification problem' was solved. However, even if recent studies have shown that recovery of alkalinity has occurred in several areas of Europe and North America (Stoddard et al., 1999, Skjelkvale et al., 2001), acidification still occurs in many areas. (Driscoll et al., 2001, Evans et al., 2001, Wright et al., 2005).

Concomitantly, a decline of base cations (mainly $\mathrm{Ca}^{2+}$ and $\mathrm{Mg}^{2+}$ ) in soils and surface waters has been reported in most areas where high rates of sulphur depositions occurred previously (Likens et al., 1996, 1998, Bouchard, 1997, Lawrence et al., 1999, Castro \& Morgan, 2000, Driscoll et al., 2001, Tessier et al., 2002). If such cation depletion continues, it will represent another serious threat to aquatic ecosystems. In addition, acidification of aquatic ecosystems is now reported across other large areas of the world, such as China (Thorjørn et al., 1999, Tang et al., 2001) and India (Aggarwal et al., 2001). Therefore, it appears that acidification of soils and water remains an important environmental problem.

One of the most striking consequences of freshwater acidification is the loss of biodiversity (Muniz, 1991). An ion-regulation failure leading to a severe deficiency of extracellular ions 
1985, Booth et al., 1988, Wood et al., 1988, McDonald et al., 1989, Potts \& McWilliams, 1989, Wood, 1989, Masson et al., 2002). Similar results have been also reported in crayfish (Morgan \& McMahon, 1982, Wood \& Ronago, 1986, McMahon \& Stuart, 1989, Jensen \& Malte, 1990), and molluscs (Malley et al., 1988, Pynnönen, 1990, 1991).

Surprisingly, and despite the numerous papers reporting detrimental effects of acidification on macroinvertebrate communities, few realistic studies have been performed to assess the ecophysiology of smaller acid-sensitive species and finally, relatively little is known about their physiological responses to short-term acid stress. In previous studies (Felten \& Guérold, 2001, 2004), we showed that Gammarus fossarum (Crustacea: Amphipoda), a common acidsensitive species in west Palearctica, also sustained a severe depletion of haemolymph $\mathrm{Na}^{+}$ and $\mathrm{Cl}^{-}$ions when exposed to acidic conditions. Conjointly, we determined relationship between acidification level and haemolymph ion losses (Felten \& Guérold, 2004).

In order to better understand the ecology of ecosystems recovering from acidification and because episodic acid-stresses generated by heavy rainfall and snowmelt continue to affect streams, the purpose of the present study was to investigate and to compare in situ the physiological responses and survival rates of three common acid-sensitive species to realistic episodic acid stress.

\section{MATERIALS AND METHODS}

Study sites. The study was performed in the Vosges Mountains (North-Eastern France). Two headwater streams located in the same area were selected because they presented very similar morphological characteristics (Table 1) but contrasted buffer capacities: a circumneutral stream (La Maix) and a strongly acidified stream (Gentil Sapin). 
Study organisms. Three macroinvertebrate species were selected because they are known to be acid-sensitive, widespread in European inland waters and easy to collect: Hydropsyche pellucidula (Trichoptera, Hydropsychidae), Dinocras cephatotes (Plecoptera, Perlidae) and Gammarus fossarum (Amphipoda, Gammaridae). Organisms were collected by using a net from a circumneutral stream, La Maix.

Experimental design. A total of 1728 males of Gammarus fossarum with 8 to $10 \mathrm{~mm}$ body lengths were collected. 288 organisms were placed in 2 Plexiglas flow-through enclosures each consisting of 18 compartments each with 8 organisms.

Conjointly, we used 216 Dinocras Cephalotes and 216 Hydropsyche pellucidula with body lengths of $20 \mathrm{~mm}$ and $15 \mathrm{~mm}$ respectively. For both species, 36 organisms were placed in 2 Plexiglas flow-through enclosures each consisting of 18 compartments $(10-\mathrm{cm}$ long and $5-\mathrm{cm}$ i.d.) each filled with 1 organism to avoid potential cannibalism.

The enclosures were then transferred to the 2 streams (circumneutral and strongly acid). For each stream, one enclosure was used for haemolymph analyses and the other for the assessment of survival. For each stream and species, there were 3 pairs of enclosure each corresponding to one exposure time $(24,72$ and $120 \mathrm{~h})$.

In order to evaluate the initial concentrations of haemolymph $\mathrm{Cl}^{-}$and $\mathrm{Na}^{+}$in each species, organisms (12 individuals for G. fossarum, 8 individuals for D. cephalotes and 8 individuals for H. pellucidula) were sampled in the neutral "native" stream just before the onset of the experiments ( $\mathrm{T}_{0}$, control). At 24, 72 and $120 \mathrm{~h}$ after exposure transfer, survival was assessed and samples of haemolymph from 8 (G. fossarum) or 6 (D. cephalotes, H. pellucidula) organisms were randomly collected in each stream for analysis (in enclosure corresponding to exposure time). The organisms were not fed during the experiment. However, the experimental design allowed drifting material (organic particles, algae and small invertebrates 
$100<1 \mathrm{~mm})$ to enter the compartments. For more details concerning enclosure technique see

101 Felten \& Guérold (2004).

102

103 Survival, haemolymph sampling and analysis. The survival was assessed in each stream for

104 each species and exposure time (G. fossarum: 3 replicates of 48 organisms; D. cephalotes and 105 H. pellucidula: 3 replicates of 6 organisms).

106 For D. cephalotes and H. pellucidula samples of haemolymph were taken from the base of the 107 cephalic capsule with a $5-\mu 1$ microcapillary tube $(\mathrm{n}=6)$. For G. fossarum, samples were taken 108 from the telson $(n=8)$ using a microsyringe and then transferred to a gauged 5- $\mu 1$ 109 microcapillary. After centrifugation of the microcapillary tubes (10 $\mathrm{min}$ at $6596 \mathrm{~g}$ ), the liquid 110 phase was diluted in $2 \mathrm{ml}$ of Nanopur water to determine chloride and sodium concentrations 111 in haemolymph by ionic chromatography (Dionex 4500i with Ion Pac AS4A column) and 112 atomic absorption spectrophotometry (AAS) (Perkin Elmer Analyst 100), respectively.

114 Water analysis. Water was collected at the initiation of the experiment $\left(\mathrm{T}_{0}\right)$ and at each 115 exposure time (24, 72 and $120 \mathrm{~h})$. Cations were analysed by flame AAS and anions by ionic 116 chromatography as described previously. Total aluminium was determined by graphite 117 furnace AAS (Varian Spectraa 300) after acidification with $0.25 \% \mathrm{HNO}_{3}$. Acid neutralising 118 capacity (ANC) was measured by Gran's titration and pH (glass electrode), and conductivity 119 with a multi-parametric equipment (WTW). Chemical characteristics of water of each stream 120 are given in Table 2.

122 Statistical analysis. All data are reported as mean \pm SD. Statistical comparisons of 123 experimental data were performed by two-way analysis of variance (ANOVA) and Ficher's 124 Least Significant Difference test (LSD). The analyses were carried out using STATISTICA 
125 (Microsoft), with a probability limit of $\mathrm{p} \leq 0.05$ considered as significant.

126

127

\section{RESULTS}

To study and compare the effect of acidification on haemolymph $\left[\mathrm{Na}^{+}\right]$and $\left[\mathrm{Cl}^{-}\right]$and survival of the 3 species, specimens were transferred from the native circumneutral stream to a strongly acidified stream. Acidified stream was characterized by low $\mathrm{pH}$ (i.e. high $\left[\mathrm{H}^{+}\right]$), low ANC, low $\left[\mathrm{Mg}^{2+}\right]$ and low $\left[\mathrm{Ca}^{2+}\right]$ and high $\left[\mathrm{Al}_{\text {tot }}\right]$. Note that, small-scale differences in mineral composition of the underlying bedrock explain the marked differences in buffering capacity, ion content and acidification (Table2). The 2-way analysis of variance (ANOVA) indicated that the factors "exposure time" and "stream" (acidification level) exerted a significant effect on haemolymph parameters $\left(\left[\mathrm{Na}^{+}\right],\left[\mathrm{Cl}^{-}\right]\right)$and survival (Table 3).

\section{Gammarus fossarum}

G. fossarum baseline levels of haemolymph $\left[\mathrm{Cl}^{-}\right]$and $\left[\mathrm{Na}^{+}\right]$on the onset of the exposure were $61.4 \pm 9.2$ and $77.5 \pm 15.5$ mmol. $\mathrm{L}^{-1}$ (mean $\pm \mathrm{SD}$ ), respectively, in control organisms collected in La Maix (Fig. 1a\&b).

Haemolymph $\left[\mathrm{Na}^{+}\right]$and $\left[\mathrm{Cl}^{-}\right]$in organisms exposed in the circumneutral stream (mean $\mathrm{pH}=$ 7.42) remained constant over the 120 -h exposure period, but significantly decreased in organisms exposed in the strongly acidic one (mean $\mathrm{pH}=4.73$ ) (Fig. 1a\&b). Indeed, in the acidic stream, the loss of haemolymph $\mathrm{Cl}^{-}$(Fig. 1a) ranged from about $44.4 \%$ after $72 \mathrm{~h}$ (mean haemolymph $\left[\mathrm{Cl}^{-}\right]=33.6 \pm 4.8 \mathrm{mmol} \cdot \mathrm{L}^{-1}$ ) to $58.7 \%$ after $120 \mathrm{~h}$ of exposure (mean haemolymph $\left.\mathrm{Cl}^{-}=23.2 \pm 3.7 \mathrm{mmol} \cdot \mathrm{L}^{-1}\right)$ compared with the control (mean haemolymph $\mathrm{Cl}^{-}=$ $\left.61.4 \pm 9.2 \mathrm{mmol} \cdot \mathrm{L}^{-1}\right)$

The same trend was observed for haemolymph $\left[\mathrm{Na}^{+}\right]$(Fig. 1b). In the acidic stream, the significant loss of haemolymph $\mathrm{Na}^{+}$ranged from $48.5 \%$ after $72 \mathrm{~h}$ of exposure (mean 
150 haemolymph $\mathrm{Na}^{+}=38.5 \pm 6.1 \mathrm{mmol} . \mathrm{L}^{-1}$ ) to $57.4 \%$ after $120 \mathrm{~h}$ of exposure (mean

151 haemolymph $\mathrm{Na}^{+}=31.1 \pm 3.5 \mathrm{mmol} . \mathrm{L}^{-1}$ ) compared with the control (mean haemolymph $\mathrm{Na}^{+}$ $\left.152=77.5 \pm 15.5 \mathrm{mmol} \cdot \mathrm{L}^{-1}\right)$.

153 For each exposure time, the survival rate in G. fossarum transferred to the circumneutral 154 stream (La Maix) remained very high and above 96\%. On the contrary, the survival rate in 155 organisms exposed to acidic water significantly decreased from $79.9 \pm 10.8 \%$ after $24 \mathrm{~h}$ of 156 exposure to $20.5 \pm 6.2 \%$ after $120 \mathrm{~h}$ of exposure (Fig. 1c).

\section{Hydropsyche pellucidula}

159 As observed for G. fossarum, the factors "exposure time" and "stream" (acidification level) 160 exerted a significant effect on haemolymph parameters $\left(\left[\mathrm{Na}^{+}\right],\left[\mathrm{Cl}^{-}\right]\right)$and survival (2-way 161 ANOVA, Table 3). H. pellucidula baseline levels of haemolymph $\left[\mathrm{Cl}^{-}\right]$and $\left[\mathrm{Na}^{+}\right]$on the onset of the exposure were $37.2 \pm 5.7$ and $132.2 \pm 8.8 \mathrm{mmol}^{-1} \mathrm{~L}^{-1}$ (mean $\pm \mathrm{SD}$ ) respectively, in control organisms collected in the neutral stream (Fig. 2a\&b).

164 Haemolymph $\left[\mathrm{Na}^{+}\right]$and $\left[\mathrm{Cl}^{-}\right]$in organisms exposed into the circumneutral stream remained 165 constant over the 120-h exposure period, but significantly decreased in organisms exposed to 166 the strongly acidic stream. Indeed, in the acidic stream, the loss of haemolymph $\mathrm{Cl}^{-}$ranged 167 from $33.6 \%$ after $24 \mathrm{~h}$ of exposure (mean haemolymph $\left[\mathrm{Cl}^{-}\right]=23.5 \pm 6.3 \mathrm{mmol} . \mathrm{L}^{-1}$ ) to $51 \%$ 168 after $120 \mathrm{~h}$ of exposure (mean haemolymph $\mathrm{Cl}^{-}=16.7 \pm 5.6 \mathrm{mmol} . \mathrm{L}^{-1}$ ) compared with the 169 control (mean haemolymph $\mathrm{Cl}^{-}=37.2 \pm 5.7$ mmol. $\mathrm{L}^{-1}$ ) (Fig. 2a).

170 A similar trend was observed for haemolymph $\left[\mathrm{Na}^{+}\right]$. In the acidic stream, the significant loss 171 of haemolymph $\mathrm{Na}^{+}$ranged from $12.1 \%$ after $24 \mathrm{~h}$ of exposure (mean haemolymph $\mathrm{Na}^{+}=$ $172120.7 \pm 5.3 \mathrm{mmol} . \mathrm{L}^{-1}$ ) to $20.8 \%$ after $120 \mathrm{~h}$ of exposure (mean haemolymph $\mathrm{Na}^{+}=100.5 \pm$

$1739.2 \mathrm{mmol} . \mathrm{L}^{-1}$ ) compared with the control (mean haemolymph $\mathrm{Na}^{+}=132.2 \pm 8.8 \mathrm{mmol} . \mathrm{L}^{-1}$ ) 174 (Fig. 2b). 
175 Throughout the exposure period the survival rate in $H$. pellucidula transferred to the

176 circumneutral stream remained very high and above 94\%. In contrast, survival decreased

177 significantly in organisms exposed to the acidic stream, where the survival rate ranged from

$17872.2 \pm 9.6 \%$ after $24 \mathrm{~h}$ of exposure to $58.3 \pm 14.4 \%$ after $120 \mathrm{~h}$ (Fig. $2 \mathrm{c}$ ).

180 Dinocras cephalotes

181 The exposure time had a significant effect on haemolymph $\left[\mathrm{Cl}^{-}\right]$and $\left[\mathrm{Na}^{+}\right]$and survival, but a 182 significant effect of stream was only observed on $\left[\mathrm{Cl}^{-}\right]$and survival (2-way ANOVA, Table

183 3). D. cephalotes baseline levels of haemolymph $\left[\mathrm{Cl}^{-}\right]$and $\left[\mathrm{Na}^{+}\right]$on the onset of the exposure 184 were $126.6 \pm 12.6$ and $133.0 \pm 6.8$ mmol. $\mathrm{L}^{-1}$ (mean $\pm \mathrm{SD}$ ), respectively, in control organisms 185 collected in the neutral stream (Fig. 3a\&b).

186 Haemolymph $\left[\mathrm{Na}^{+}\right]$and $\left[\mathrm{Cl}^{-}\right]$in D. cephalotes exposed into the circumneutral stream 187 remained constant over the 120-h exposure period. In organisms exposed into the acidic 188 steam, a significant loss was observed only after $120 \mathrm{~h}$ of exposure. The loss of haemolymph $189 \mathrm{Cl}^{-}$and $\mathrm{Na}^{+}$reached respectively $20.6 \%$ (mean haemolymph $\left[\mathrm{Cl}^{-}\right]=96.7 \pm 17.3 \mathrm{mmol} \cdot \mathrm{L}^{-1}$ ) 190 and $13.1 \%$ (mean haemolymph $\mathrm{Na}^{+}=109.3 \pm 22.2$ mmol. $\mathrm{L}^{-1}$ ) compared with the control 191 (mean haemolymph $\mathrm{Cl}^{-}=126.6 \pm 12.6$ mmol.L $\mathrm{L}^{-1}$; mean haemolymph $\mathrm{Na}^{+}=133.0 \pm 6.8$ 192 mmol.L $\left.\mathrm{L}^{-1}\right)$

193 No mortality was observed in D. cephalotes transferred to the circumneutral stream (La Maix)

194 during the experiment. Survival rate in organisms exposed to the acidic stream remained also 195 high after $24 \mathrm{~h}$, but decreased significantly after $72 \mathrm{~h}$ and $120 \mathrm{~h}$ exposure (reaching $83.3 \pm$ $1968.3 \%$, Fig. 3c).

\section{Species sensitivity comparison}

199 The baseline level of haemolymph $\left[\mathrm{Cl}^{-}\right]$in $D$. cephalotes was respectively 2 and 3.5 times 
higher than in G. fossarum and H. pellucidula. Haemolymph $\left[\mathrm{Na}^{+}\right]$baseline levels in $D$. 201 cephalotes an $H$. pellucidula were similar and 1.8 times higher than in G. fossarum. 202 Haemolymph $\left[\mathrm{Na}^{+}\right]$was always higher than $\left[\mathrm{Cl}^{-}\right]$representing a difference of $5 \%, 21.7 \%$ and 74.4\% in D. cephalotes, G. fossarum and H. pellucidula, respectively.

204 Under the experimental conditions of this study, D. cephalotes was the least acid-sensitive 205 species, since it presented the lowest ion losses and mortality rate. G. fossarum was the most 206 acid-sensitive species, showing both the highest losses of ions and mortality.

\section{DISCUSSION}

209 Over recent years, the loss of biodiversity has become a major concern (see Gaston, 2000, 210 Loreau et al., 2001, Naeem et al., 1999). Acidification of freshwater due to anthropogenic 211 activities has been recognized as an important cause of biodiversity loss in ecosystems located 212 in remote areas. In the Vosges Mountains, acidification of headwater streams has been 213 identified as being the major threat to aquatic biota. Acidified streams are strongly 214 impoverished. For example, macroinvertebrate communities have lost between 50 and $70 \%$ of 215 the original species (Guérold et al., 2000).

216 Although all major taxonomic groups are affected by acidification, species sensitivity appears 217 different among macroinvertebrates groups. Studies carried out in Europe and in North 218 America have highlighted the high sensitivity of molluscs, Ephemeroptera and crustacean 219 (Hall et al., 1980, Harriman \& Morison, 1982, Sutcliffe, 1983, Engblom \& Lingbell, 1984, 220 Perterson et al., 1985, Guérold et al., 2000). The response of Trichoptera to acidification is 221 more variable: several species disappear (e.g Hydropsyche sp.) whereas some others exhibit higher densities (e.g. Plectrocnemia conspersa). Thus, many works have reported the acidsensitivity of Hydropsychidae and Philopotamidae as well as the acid-tolerance of

224 Plectrocnemia, Rhyacophyla and Limnephilidae (Sutcliffe \& Carrick, 1973, Ziemann, 1975, 
Harriman \& Morrison, 1982, Havas \& Hutchinson, 1982, Townsend et al., 1983, Raddum \& 226 Fjellheim, 1984, Simpson et al., 1985). Although Perlidae (e.g., Dinocras cephalotes) and, to 227 a lesser extent, Perlodidiae are recognized as being acid-sensitive, the majority of Plecoptera 228 (especially Nemouridae and Leuctridae) are acid-tolerant and can be very abundant in acid 229 streams (Sutcliffe \& Carrick, 1973, Raddum \& Fjellheim, 1984, Tixier \& Guérold, 2005).

230 The toxicity of acid water seems to be the principal hypothesis (often referred to as the 231 ecotoxicological hypothesis) explaining the loss of species. In the present study we showed 232 that a short-term exposure of G. fossarum, H. pellucidula and D. cephalotes to strongly 233 natural acidic water caused significant losses of haemolymph $\left[\mathrm{Na}^{+}\right]$and $\left[\mathrm{Cl}^{-}\right]$accompanied by 234 significant mortality. However, the intensity and rapidity of ion loss depends on the species 235 considered: in G. fossarum and H. pellucidula significant ion losses occurred as early as $24 \mathrm{~h}$ 236 of exposure in an acidic stream whereas in D. cephalotes a significant decrease of 237 haemolymph $\left[\mathrm{Cl}^{-}\right]$and $\left[\mathrm{Na}^{+}\right]$was observed only after $120 \mathrm{~h}$ of exposure.

238 The magnitude of ion loss also differs among species: after $120 \mathrm{~h}$ of exposure in acidic stream, 239 haemolymph $\left[\mathrm{Cl}^{-}\right]$and $\left[\mathrm{Na}^{+}\right]$losses reached respectively $58.7 \%$ and $57.4 \%$ in G. fossarum, $24051 \%$ and $20.8 \%$ in H. pellucidula and only $20.6 \%$ and $13.1 \%$ in D. cephalotes. Similarly, the 241 lowest survival rate was observed for G. fossarum (20.5\%), the highest for D. cephalotes $242(83.3 \%)$ whereas it was intermediate for H. pellucidula $(58.3 \%)$.

243 Although some studies have clearly identified a depletion of ion concentrations in invertebrate 244 exposed to acidic waters, most of these studies were performed on moderately acid-sensitive 245 species (Corixia dentipes, C. punctata: Vangenechten et al., 1989; Cenocorixia blaisdelli: 246 Needham, 1990; Libellula julia: Rockwood \& Coler, 1991; Pteronarcys proteus: Leichleitner 247 et al., 1985) and/or on organisms experimentally exposed to conditions that were not 248 environmentally meaningful; e.g. pH 2.8-3.0 (Lechleitner et al., 1985; pH 3.0, Rupprecht, 249 1992) or aluminium concentrations of $30 \mathrm{mg} . \mathrm{L}^{-1}$ (Rockwood \& Coler, 1991). Similar results 
have also been obtained from pooled samples of haemolymph (Needham, 1990) or from

251 whole body analyses (Hermann, 1987, Rowe et al. 1988, 1989, Havens, 1992).

252 Because of the protocol and the realistic in situ conditions of exposure, our results study 253 provides more rigorous results and consolidates the experimental studies previously 254 mentioned (see above). There is no doubt that significant ion loss and mortality in acid 255 sensitive species can be induced by short exposures to acidic stresses. This is particularly 256 pertinent to running water ecosystems experiencing acute acid stresses that are, for most of 257 the time, within the $\mathrm{pH}$ range that could sustain such taxa. For example, in the Vosges 258 Mountains, several circumneutral streams draining sandstone are subjected to rare acid 259 stresses. These streams exhibit communities of invertebrates that are rather typical of 260 moderately acidified streams despite their average chemical characteristics.

261 Depending on their duration, magnitude and frequency, such acid stresses can lead to the loss 262 of sensitive species or simply impair their abundances. This has been recently evidenced by 263 Lepori and Ormerod (2005) who have shown that the distribution and the density of the 264 bivoltine species, Baetis alpinus (Ephemeroptera) in areas subjected to acidification in the 265 Alps, depend on the toxicity of acid run-off during snowmelt. However, concerning species 266 which are monovoltine or semi-voltine, repeated acid stresses are more likely to eradicate 267 them from sensitive ecosystems.

268 Finally, our results sustain the hypothesis proposed by Bradley and Ormerod (2002) that short 269 episodes of low $\mathrm{pH}$ can offset the recovery of sensitive species of macroinvertebrates in 270 streams that have chemically recovered from acidification following catchment liming.

271 Understanding both the biological effect and ecological consequences of episodic acidity has 272 real management implications in defining strategies. Given the general context of recovery 273 from acidification, in response to reduced acidic depositions as well as following liming, the 274 use of physiological variables such as haemolymph $\left[\mathrm{Cl}^{+}\right]$and $\left[\mathrm{Na}^{-}\right]$, would be helpful to 
275 predict whether the ecosystem meets again the chemical quality that can allow the re276 colonization of acid-sensitive species. Likewise, the development and the use of methods 277 based on macroinvertebrate communities would provide important information of ecological 278 relevance (for example on the settlement of sensitive species populations and the 279 sustainability of these populations). Finally, in the context of ecological toxicology (sensu 280 Chapman, 2002) a combination of both approaches would greatly enhance the pertinence of 281 biological monitoring with minimal uncertainty, especially in national or international survey 282 programs aiming to assess the consequences of the reduction of atmospheric emissions of 283 acidic pollutants as well as the effectiveness of liming.

Acknowledgements. We are grateful to Marie-Danielle Murard and two anonymous referees 286 for helpful comments and linguistic corrections to improve the manuscript.

\section{LITERATURE CITED}

291 Aggarwal, S.G., Chandrawanshi, K., Patel, R.M., Agarwal, S., Kamavishdar, A., Mundhara, G., 2001. Acidification of surface water in central India. Water Air Soil Poll.. 130:855-862.

294 low $\mathrm{pH}$ on net ion fluxes and ion balance in the brook trout (Salvelinus fontinalis). Can J 295 Fish Aquat Sci 45 (9), 1563-1574.

296 Bouchard, A., 1997. Recent lakes acidification and recovery trends in southern Quebec, 297 Canada. Water Air Soil Poll. 94, 225-245.

298 Bradley, D.C., Ormerod, S.J., 2002. Long term effects of catchment liming on invertebrates in 299 upland streams. Freshwater Biol 47, 161-171 
Castro, M.S., Morgan, II R.P., 2000. Input-output budgets of major ions for a forested watershed in western Maryland. Water Air Soil Poll. 119, 121-137.

Chapman, P.M., 2002. Integrating toxicology and ecology: putting the "eco" into 303 ecotoxicology. Mar Pollut Bull 44, 7-15.

304 Driscoll, C.T., Lawrence, G.B., Bulger, A.J., Butler, T.J., Cronan, C.S., Eagar, C., Lambert, 305 K.F., Likens, G.E., Stoddard, J.L., Weathers, K.C., 2001. Acidic deposition in the 306 northeastern United States: sources and inputs, ecosystem effects, and management 307 strategies. BioScience 51, 180-198.

308 Engblom, E., Lingbell, P.E., 1984. The mapping of short-term acidification with the help of 309 biological indicators. Institute of freshwater Research, Drottingholm, report 61, 60-68.

310 Evans, C.D., Harriman, R., Monteih, D.T., Jenkins, A., 2001. Assessing the suitability of acid 311 neutralizing capacity as a measure of long-term trends in acidic waters based on two parallel 312 datasets. Water Air Soil Poll. 130, 1541-1546.

313 Felten, V., Guérold, F., 2001. Hyperventilation and loss of haemolymph $\mathrm{Na}^{+}$and $\mathrm{Cl}^{-}$in the 314 freshwater amphipod Gammarus fossarum exposed to acid stress: a preliminary study. Dis 315 Aquat Organ 45, 77-80.

316 Felten, V., Guérold, F., 2004. Haemolymph $\left[\mathrm{Na}^{+}\right]$and $\left[\mathrm{Cl}^{-}\right]$loss in Gammarus fossarum 317 exposed in situ to a wide range of acidic streams. Dis Aquat Organ 61, 113-121.

318 Folster, J., Wilander, A., 2002. Recovery from acidification in Swedish forest streams. 319 Environ Pollut 117, 379-89.

320 Gaston, K.J., 2000. Global patterns in biodiversity. Nature 405, 220-227.

321 Guérold, F., Boudot, J.P., Jacquemin, G., Vein, D., Merlet, D., Rouiller, J., 2000. 322 Macroinvertebrate community loss as a result of headwater stream acidification in the 323 Vosges Mountains (N-E France). Biodivers Conserv 9, 767-783. 
Hall, R.J., Likens, G.E., Fiance, S.B. \& Hendrey, G.R., 1980. Experimental acidification of a stream in the Hubbard brook experimental forest, New Hampshire. Ecology 61, 976-989.

Harriman, R., Morrison, B.R.S., 1982. Ecology of streams draining forested and non-forested catchments in an area of central Scotland subject to acid precipitation. Hydrobiologia 88, $251-263$.

Havas, K.E., Hutchinson, T.C., 1982. Aquatic invertebrate from the smoking hills: effect of pH and metals on mortality. Can J Fish Aquat Sci 39, 890-903.

Havens, K.E., 1992. Acid and aluminium effects on sodium homeostasis and survival of acidsensitive and acid-tolerant Cladocera. Can J Fish Aquat Sci 49, 2392-2398.

Hermann, J., 1987. Sodium levels of lotic mayfly nymphs being exposed to aluminium at low pH. A preliminary report. Ann Soc R Zool Belg 117, 188-191.

Jensen, F.B., Malte, H., 1990. Acid-base and electrolyte regulation, and hemolymph gas transport in crayfish Astacus astacus, exposed to soft, acid water with and without aluminum. J Comp Physiol B 160, 483-490.

Lawrence, G.B., David, M.B., Lovett, G.M., Murdoch, P.S., and 5 others, 1999. Soil calcium status and the response of stream chemistry to changing acidic deposition rates in the

340 Catskill Mountains of New York. Ecol Appl 9, 1059-1072.

Lawrence, G.B., Lovett, G.M., Baevsky, Y.H., 2000. Atmospheric deposition and watershed

342 nitrogen export along an elevational gradient in the Catskill Mountains, New York. 343 Biogeochemistry 50, 21-43.

344 Lechleitner, R., Cherry, D., Cairns, J., Stetler, D., 1985. Ionoregulatory and toxicological 345 responses of stonefly nymphs (Plecoptera) to acidic and alkaline $\mathrm{pH}$. Arch Environ Con Tox $346 \quad 14,179-185$.

347 Lepori F., Ormerod S.J., 2005. Effects of spring acid episodes on macroinvertebrates revealed 348 by population data and in situ toxicity tests. Freshwater Biol 50, 1568-1577 
Likens, G.E., Driscoll, C.T., Buso, D.C., 1996. Long-term effects of acid rain: response and recovery of a forest ecosystem. Science $272,244-246$.

351 Likens, G.E., Driscoll, C.T., Buso, D.C., Siccama, T.G., and 7 others, 1998. The 352 biogeochemistry of calcium at Hubbard Brook. Biogeochemistry 41, 89-173.

353 Likens, G.E., Butker, T.J., Buso, D.C., 2001. Long- and short-term changes in sulphate 354 deposition: effects of the 1990 Clean Air Act Amendments. Biogeochemistry 52, 1-11.

355 Loreau, M., Naeem, S., Inchausti, P., Bengtsson, J., Grime, J.P., Hector, A., Hooper, D.U., 356 Huston, M.A., Raffaelli, D., Schmid, B., Tilman D., Wardle D.A., 2001. Biodiversity and 357 ecosystem functioning: current knowledge and future challenges. Science 294, 804-808.

358 Malley D.F., Huebner J.D. \& Donkersloot K., 1988. Effects on ionic composition of blood 359 and tissues Anodonta grandis grandis (Bivalvia) of an addition of aluminum and acid to 360 lake. Arch Environ Con Tox 17, 479-491.

361 Masson, N., Guérold, F., Dangles, O., 2002. Use of blood parameters in fish to assess acidic 362 stress and chloride pollution in French running waters. Chemosphere 47, 467-473.

363 McDonald, D.G., Reader, J.P., Dalziel, T.R.K., 1989. The combined effects of pH and trace 364 metals on fish ionoregulation. In: Morris, R., Taylor, E.W., Brown, D.J.A., Brown, J.A., 365 (Eds.) Acid toxicity and aquatic animals. Cambridge University Press, Cambridge, pp. 221366242.

367 McMahon, B.R., Stuart, S.A., 1989. The physiological problem of crayfish in acid water. In: 368 Morris, R., Taylor, E.W., Brown, D.J.A., Brown, J.A. (Eds.) Acid toxicity and aquatic 369 animals. Cambridge University Press, Cambridge, pp. 171-200.

370 Morgan, I.J., McMahon, B.R., 1982. Acid tolerance and effects of sublethal acid exposure on 371 iono-regulation and acid-base status in two crayfish Procambarus clarki and Oronectes 372 rusticus. J Exp Biol 97, 241-252. 
373 Muniz, I.P., 1991. Freshwater acidification: its effects on species and communities of 374 freshwater microbes, plants and animals. P Roy Soc Edinb B 97, 227-254.

375 Naeem, S., Chapin III, F.S., Costanza, R., Ehrlich, P.R., Golley, F.B., Hooper, D.U., Lawton, 376 J.H., O'Neill, R.V., Mooney, H.A., Sala, O.E., Symstad, A.J., Tilman, D., 1999. 377 Biodiversity and ecosystem functioning: Mantaining life support processes. Issues in 378 Ecology 4, 1-11.

379 Needham, K.M., 1990. Specific and seasonal variation in survival and sodium balance at low $380 \mathrm{pH}$ in five species of waterboatman (Hemiptera Corixidae). MS, University of British 381 Columbia, Vancouver.

382 Neville, C.M., 1985. Phylosiological responses of juvenile rainbow trout, Salmo gairderi to 383 acid and aluminum - prediction of field responses from laboratory data. Can J Fish Aquat 384 Sci, 42, 2004-2019.

385 Peterson R.H., Gordon D.J. \& Johnston, D.J., 1985. Distribution of mayfly nymphs (Insecta 386 Ephemeroptera) in some streams of Eastern Canada as related to stream pH. Can. Field. $387 \quad$ Nat. 99, 490-493.

388 Potts, W.T.W., McWilliams, P.G., 1989. The effect of hydrogen and aluminum ions on fish 389 gills. In: Morris, R., Taylor, E.W., Brown, D.J.A., Brown, J.A. (Eds.) Acid toxicity and 390 aquatic animals. Cambridge University Press, Cambridge, pp. 201-220.

391 Pynnönen, K., 1990. Physiological responses to severe acid stress in four species of 392 freshwater Clams (Unionidae). Arch Environ Con Tox 19, 471-478.

393 Pynnönen, K., 1991. Influence of aluminum and protons on the electrolyte homeostasis in the 394 Unionidae Anodonta anatina and Unio pictorum. Arch. Environ Cont Tox 20, 218-225.

395 Raddum, G.G., Fjellheim, A., 1984. Acidification and early warning organisms in freshwater 396 in western Norway. Verh. Internat. Verein. Limnol. 22, 1973-1980. 
Rockwood, J.P., Coler, R.A., 1991. The effect of aluminum in soft water at low pH on water 398 balance and hemolymph ionic and acid-base regulation in the dragonfly Libellula julia $399 \quad$ Uhler. Hydrobiologia 215, 243-250.

400 Rowe, L., Berrill, M., Hollett, L., 1988. The influence of season and pH on mortality, molting 401 and whole-body ion concentrations in nymphs of the mayfly Stenonema femoratum.- Comp. $402 \quad$ Biochem. Physiol. 90 A (3), 405-408.

403 Rowe, L., Berrill, M., Hollett, L., Hall, R.J., 1989. The effects of short-term laboratory pH 404 depressions on molting, mortality and major ion concentrations in the mayflies Stenonema 405 femoratum and Leptophlebia cupida. Hydrobiologia 184, 89-97.

406 Rupprecht, R., 1992. Zu den Ursachen der unterschiedlichen pH-Empfindlichkeit von 407 Gammarus pulex L., G. fossarum Koch (Amphipoda) und Asellus aquaticus L. (Isopoda). 408 Int. Rev. Gesamt. Hydrobiol. 77(2), 255-264.

409 Simpson, K.W., Bode, R.W., Colquhoun, J.R., 1985. The macroinvertebrate fauna of an acid 410 stream system in the Adirondack Mountains, New York. Freshwater Biol. 15, 671-681.

411 Skjelkvale, B.L., Torseth, K., Aas, W., Andersen, T., 2001. Decrease in acid deposition412 recovery in Norwegian waters. Water Air Soil Poll. 130, 1433-1438.

413 Stoddart, J.L., Jeffries, D.S., Lukewille, A., Clair, T.A., and 19 others, 1999. Regional trends 414 in aquatic recovery from acidification in North America and Europe. Nature 401(6753), $415 \quad 575-578$.

416 Sutcliffe, D.W., Carrick, T.R., 1973. Studies on mountain streams in the English Lake 417 District. I. PH, calcium and the distribution if invertebrates in the River Duddon. Freshwater 418 Biol 3, 437-462.

419 Sutcliffe, D.W., 1983. Acid precipitation and its effects on aquatic systems in the English 420 Lake District (Cumbria).- Freshwater Biological Association Annual Report 51, 30-62. 
Tang, D., Lydersen, E., Seip, H.M., Angell, V., and 11 others, 2001. Integrated monitoring program on acidification of Chinese terrestrial systems (impacts)—A Chinese-Norwegian collaboration project. Water Air Soil Poll. 130, 1073-1078.

Tessier, J.T., Masters, R.D., Raynal, D.J., 2002. Changes in base cation deposition across New York State adjacent New England following implementation of the 1990 Clean Air Act amendments. Atmos Environ 36, 1645-1648.

Thorjørn, L., Seip, H.M., Semb, A., Mulder, J., and 6 others, 1999. Acid deposition and its effects in China: an overview. Environ Sci Policy 2, 9-24.

Tixier G., Guérold F. 2005. Plecoptera Response to acidification in several headwater streams in the Vosges Mountains (North-Eastern France). Biodivers Conserv 14 : 1525-1539

Townsend, C.R., Hildrew, A.G., Francis, J.E., 1983. Community structure in some southern English streams: the influence of physicochemical factors. Freshwater Biol. 13, 521-544.

Vangenechten, J.H.D., Witters, H., Vanderborght, O.L.J., 1989. Laboratory studies on invertebrate survival and physiology in acid waters. In: Morris R, Taylor EW, Brown DJA, Brown JA (Eds.) Acid toxicity and aquatic animals. Cambridge University Press, Cambridge, pp. 153-170.

Wood, C.M., Rogano, M.S., 1986. Physiological responses to acid stress in crayfish (Orconectes): Heamolymph ions, acid-base status, and exchanges with the environment. Can J Fish Aquat Sci 43, 1017-1026.

Wood, C.M., Playle, R.L., Simons, B.P., Goss, G.C., McDonald, D.G., 1988. Blood gases, acid base status, ions and haematology in adult brook trout (Salvelinus fontinalis) under acid/aluminum exposure. Can J Fish Aquat Sci 45, 1575-1586.

Wood, C.M., 1989. The physiological problems of fish in acid water. In: Morris, R., Taylor, E.W., Brown, D.J.A., Brown, J.A. (Eds.) Acid toxicity and aquatic animals. Cambridge University Press, Cambridge, pp. 125-152. 
446 Wright, R.F., Larssen, T., Camarero, L., Cosby, B.J., Ferrier, R.C., Helliwell, R., Forsius, M., 447 Jenkins, A., Kopácek, J., Majer, V., Moldan, F., Posch, M., Rogora, M., Schöpp, W., 2005. 448 Recovery of acidified European Surface waters. Environ Sci and Technol 39, 64-72.

449 Ziemann, H., 1975. Uber den Einfluss des Wasserstoffionenkonzentration und des 450 Hydrogenkarbonatgehaltes auf die Ausbildung von Berbachbiozönosen. Int. Rev. Ges. $451 \quad$ Hydrobiol. $60: 523-555$.

452

453

454

455

456

457

458

459

460

461

462

463

464

465

466

467

468

469

470 


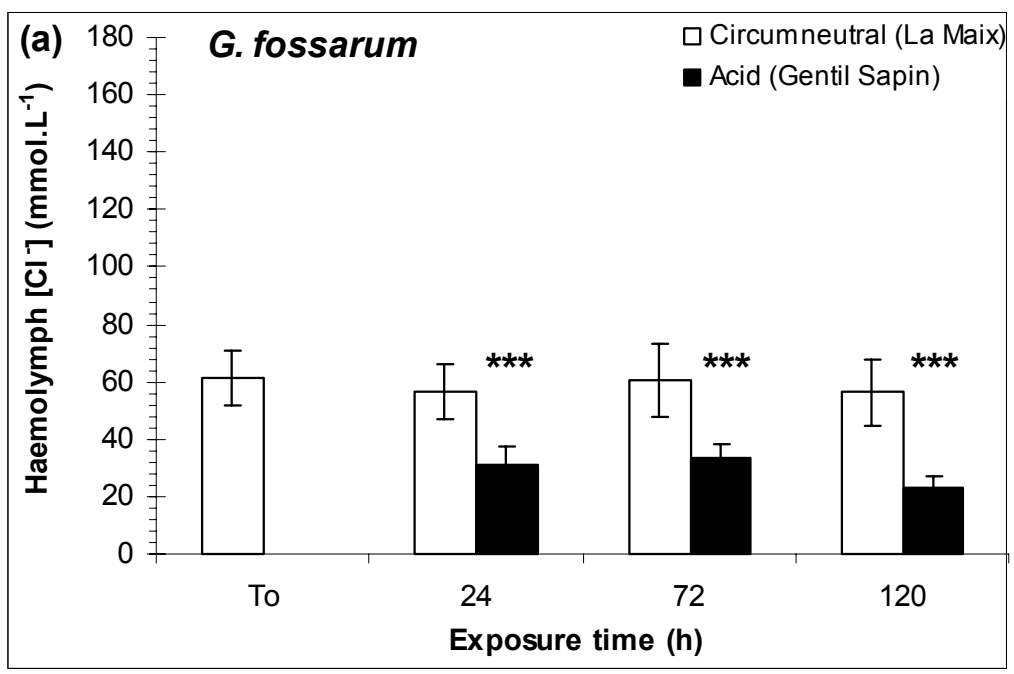

Exposure time (h)
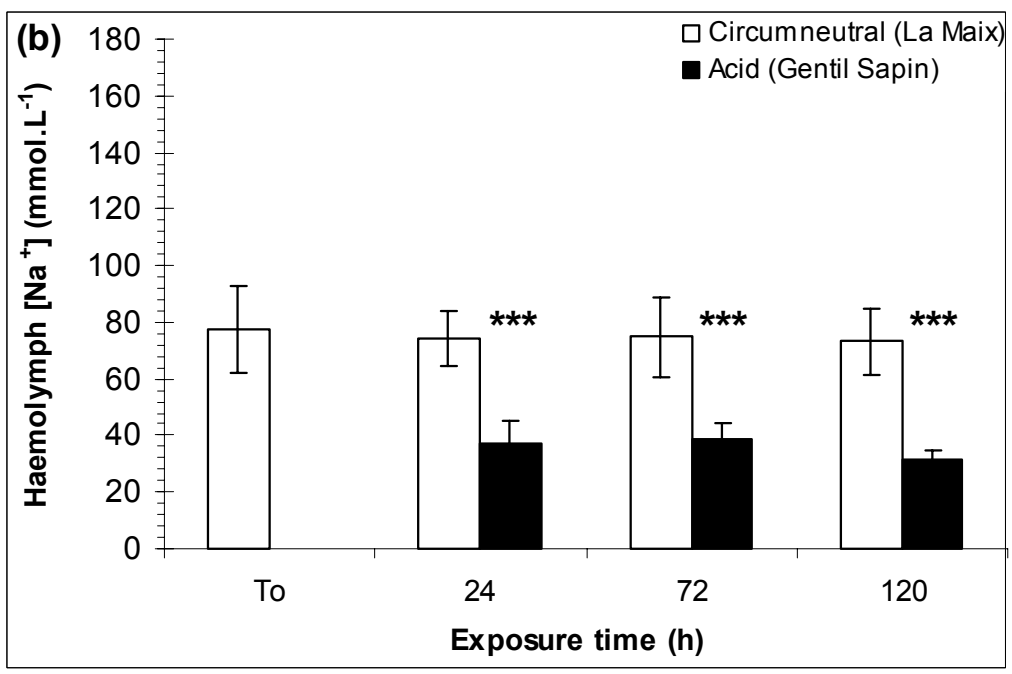

485
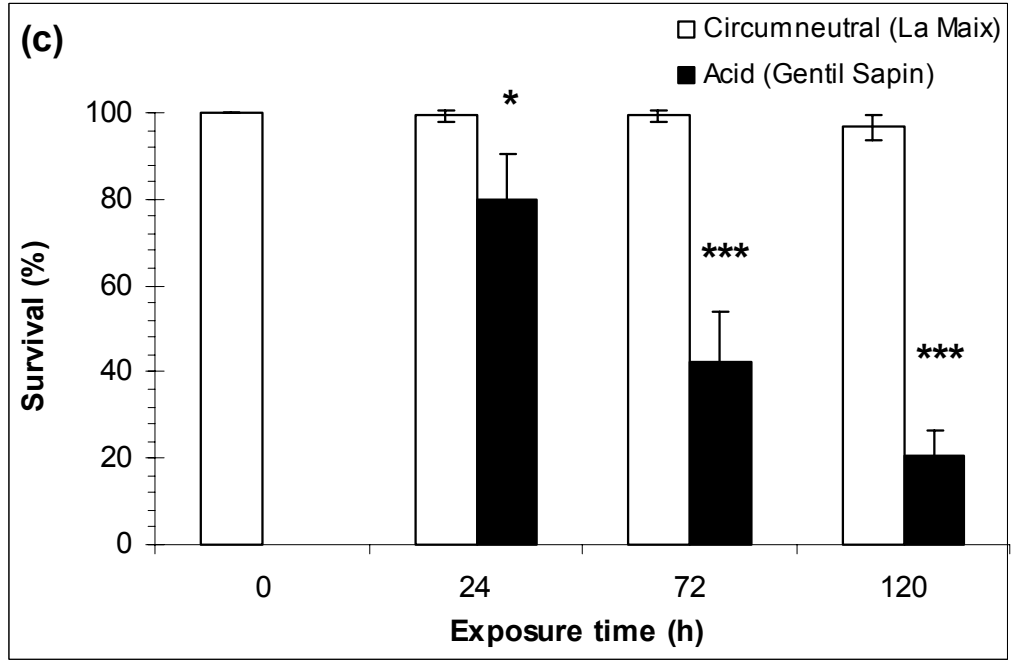

492 Figure 1. Mean ( \pm SD) $\left[\mathrm{Cl}^{-}\right]$haemolymph (a), $\left[\mathrm{Na}^{+}\right]$haemolymph (b), and survival (c) of 493 Gammarus fossarum exposed to circumneutral and acidic water. Significant differences 494 against $\mathrm{T}_{0}$ are indicated by asterisks (Ficher's Least Significant Difference test; $*: \mathrm{p}<0.05$; $* *: \mathrm{p}<0.01 ; * * *: \mathrm{p}<0.001)$ 


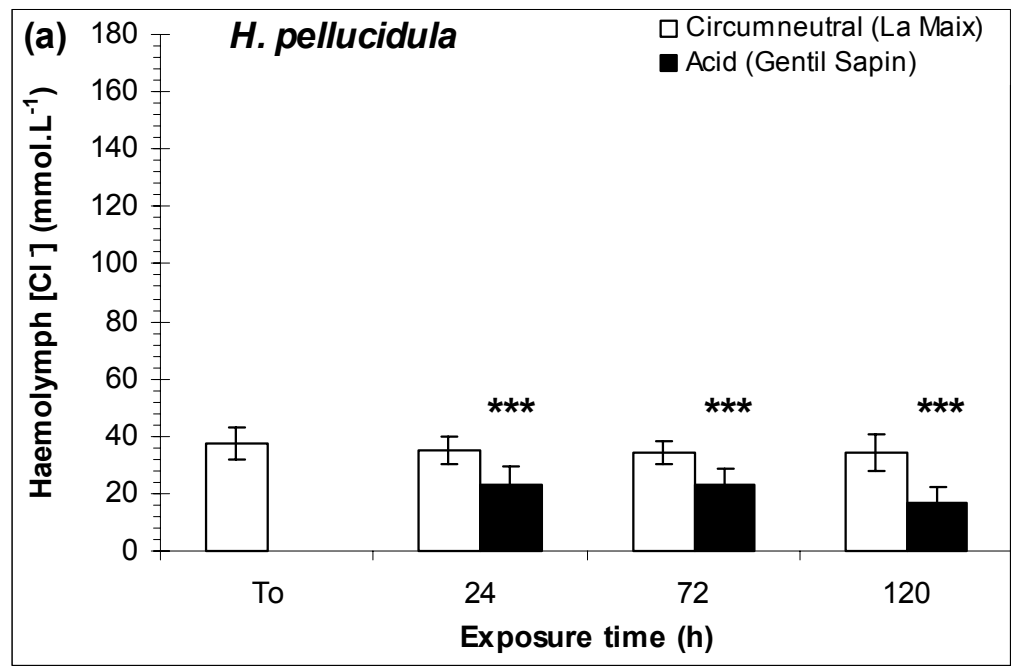

503

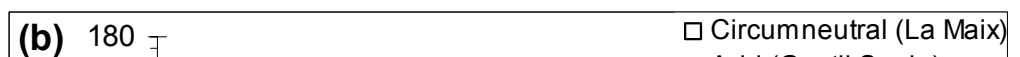

504

505

506

507

508

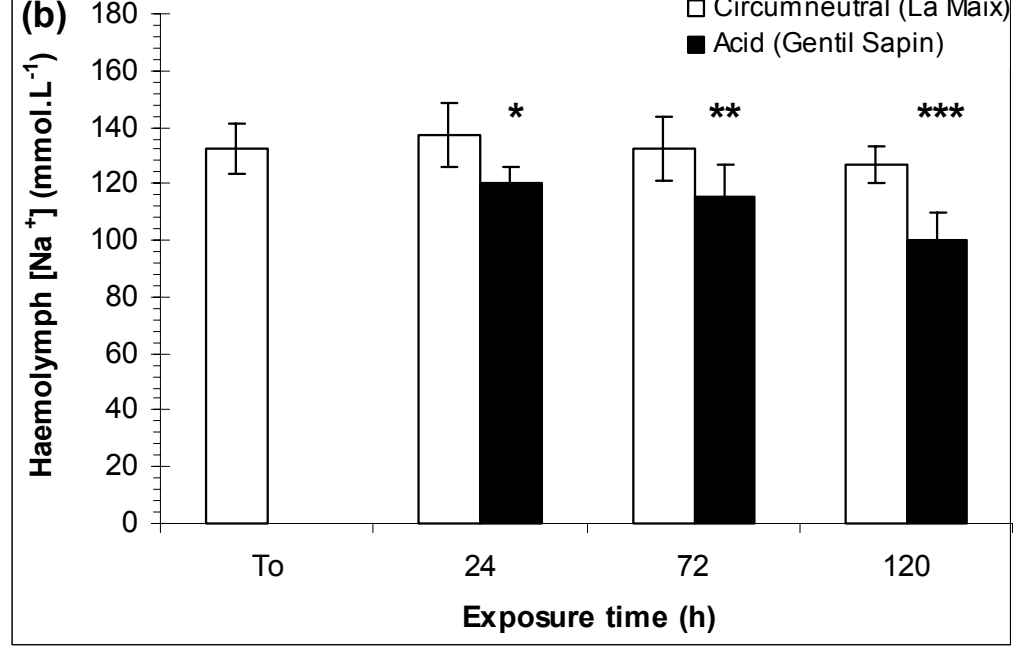

510

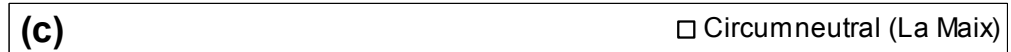
- Acid (Gentil Sapin)

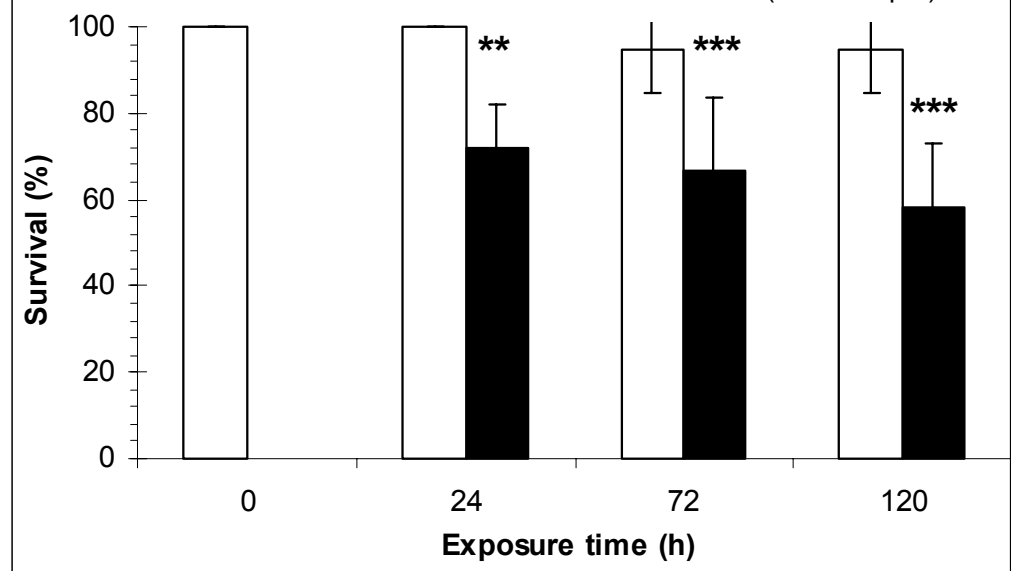

517 Figure 2. Mean ( \pm SD) $\left[\mathrm{Cl}^{-}\right]$haemolymph (a), $\left[\mathrm{Na}^{+}\right]$haemolymph (b), and survival (c) of

518 Hydropsyche pellucidula exposed to circumneutral and acidic water. Significant differences

519 against $\mathrm{T}_{0}$ are indicated by asterisks (Ficher's Least Significant Difference test; * $: \mathrm{p}<0.05$; $* *: \mathrm{p}<0.01 ; * * *: \mathrm{p}<0.001)$ 


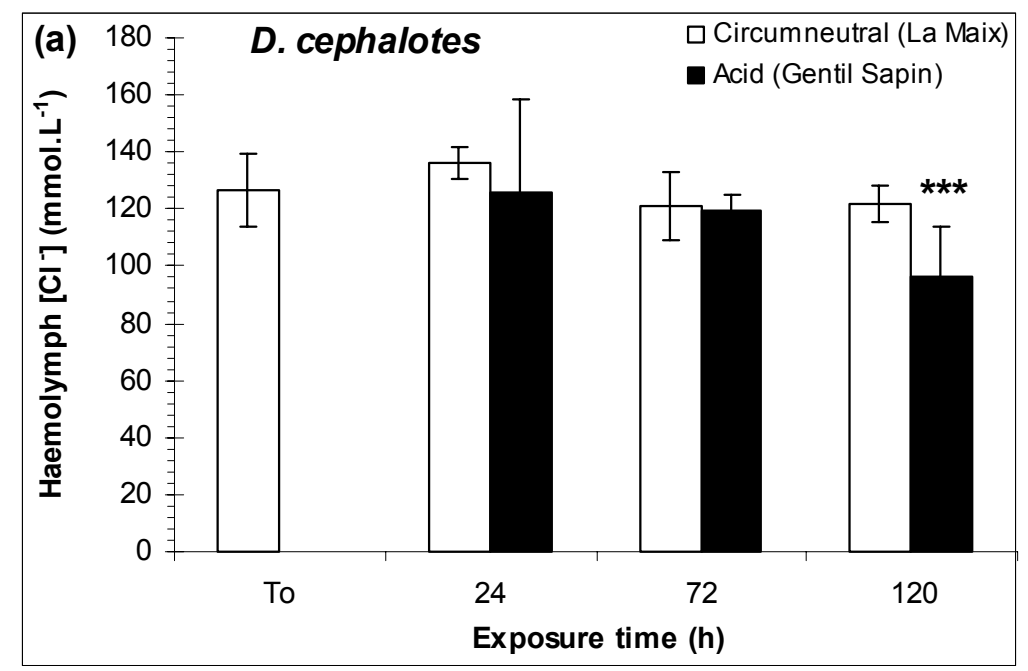

528
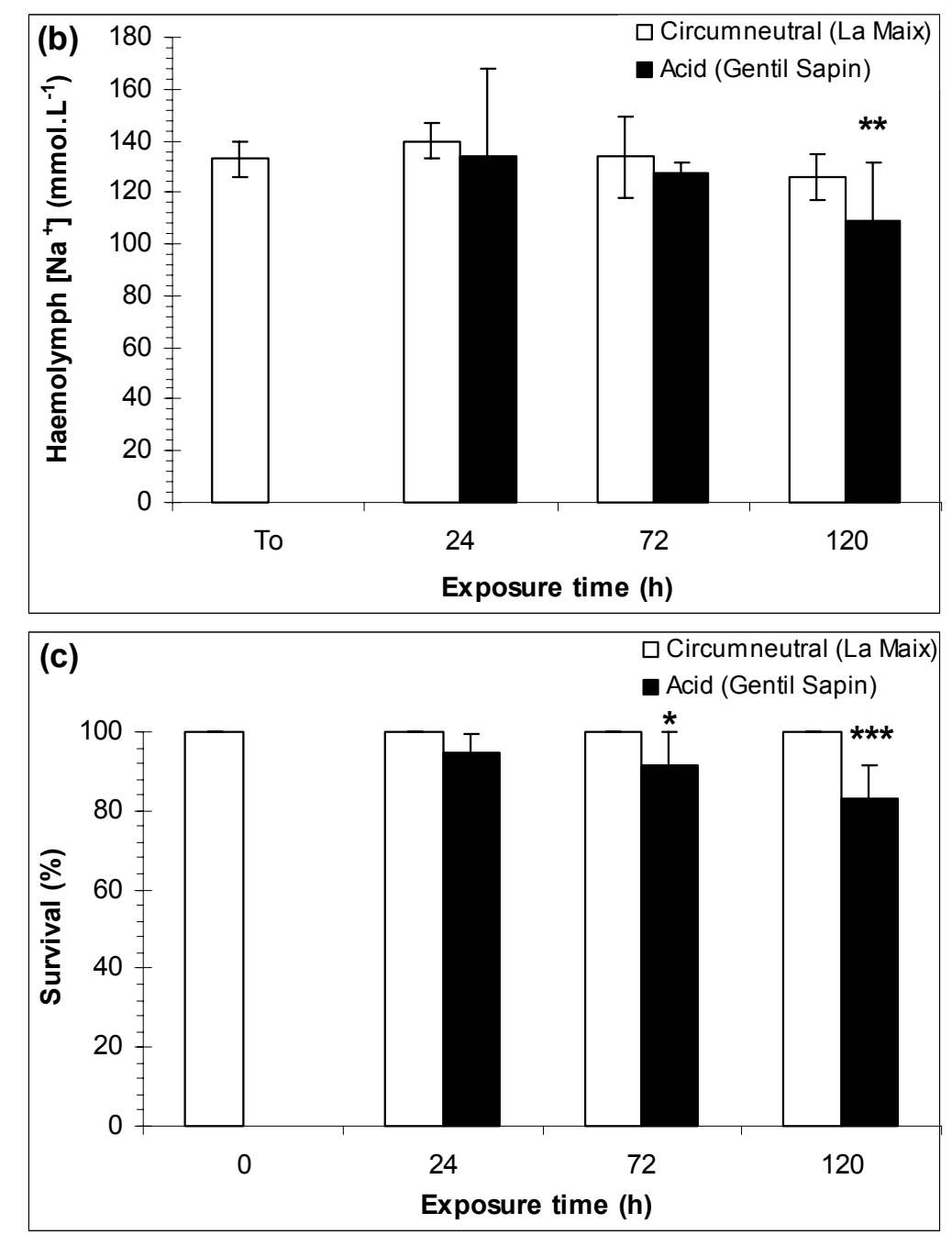

542 Figure 3. Mean $( \pm \mathrm{SD})\left[\mathrm{Cl}^{-}\right]$haemolymph (a), $\left[\mathrm{Na}^{+}\right]$haemolymph (b), and survival (c) of 543 Dinocras cephalotes exposed to circumneutral and acidic waters. Significant differences 544 against $\mathrm{T}_{0}$ are indicated by asterisks (Ficher's Least Significant Difference test; $* \mathrm{p}<0.05$; $* *: \mathrm{p}<0.01 ; * * *: \mathrm{p}<0.001)$ 
Table 1. Description of the two study sites.

548

550

552

554

556

558

\begin{tabular}{lcc}
\hline \multicolumn{1}{c}{ stream name } & La Maix & Gentil Sapin \\
\hline stream order & 2 & 2 \\
elevation $(\mathrm{m})$ & 439 & 501 \\
distance from spring $(\mathrm{m})$ & 3870 & 3280 \\
latitude N & $48^{\circ} 29^{\prime} 02.1^{\prime \prime}$ & $48^{\circ} 26^{\prime} 56.8^{\prime \prime}$ \\
longitude E & $007^{\circ} 04^{\prime} 08.5^{\prime \prime}$ & $007^{\circ} 03^{\prime} 33.5^{\prime \prime}$ \\
width $(\mathrm{m})$ & 1.8 & 2.3 \\
depth $(\mathrm{m})$ & 0.35 & 0.30 \\
\hline
\end{tabular}

559

560

561

562

563

564

565

566

567

568

569

570

571

572

573

574

575 
Table 2. Mean $( \pm S D)$ values of various chemicals of each exposure stream $(n=4)$. ANC: Acid

577 Neutralizing Capacity.

578

579

580

581

582

583

584

585

586

587

588

\begin{tabular}{|c|c|c|c|c|}
\hline & \multicolumn{2}{|c|}{ La Maix } & \multicolumn{2}{|c|}{ Gentil Sapin } \\
\hline & Mean & SD & Mean & $\mathrm{SD}$ \\
\hline $\mathrm{pH}$ & 7,42 & 0,13 & 4,73 & 0,08 \\
\hline Temperature $\left({ }^{\circ} \mathrm{C}\right)$ & 11,9 & 0,7 & 14,0 & 1,5 \\
\hline conductivity $\left(\mu \mathrm{S} . \mathrm{cm}^{-1}\right)$ & 74,3 & 4,3 & 31,5 & 2,4 \\
\hline $\mathrm{ANC}\left(\mu\right.$ eq. $\left.\mathrm{L}^{-1}\right)$ & 618,3 & 13,5 & $-15,5$ & 7,0 \\
\hline $\mathrm{Ca}^{2+}\left(\mu \mathrm{mol} \cdot \mathrm{L}^{-1}\right)$ & 222,9 & 3,1 & 39,1 & 0,6 \\
\hline $\mathrm{Mg}^{2+}\left(\mu \mathrm{mol} . \mathrm{L}^{-1}\right)$ & 188,3 & 0,8 & 28,6 & 0,2 \\
\hline $\mathrm{Na}^{+}\left(\mu \mathrm{mol} \cdot \mathrm{L}^{-1}\right)$ & 64,1 & 0,4 & 49,4 & 1,4 \\
\hline $\mathrm{K}^{+}\left(\mu \mathrm{mol} \cdot \mathrm{L}^{-1}\right)$ & 56,4 & 0,3 & 35,4 & 1,3 \\
\hline $\mathrm{SO}_{4}^{2-}\left(\mu \mathrm{mol} . \mathrm{L}^{-1}\right)$ & 75,7 & 0,6 & 62,5 & 0,8 \\
\hline $\mathrm{NO}_{3}^{-}\left(\mu \mathrm{mol} \cdot \mathrm{L}^{-1}\right)$ & 60,0 & 0,9 & 88,5 & 1,1 \\
\hline $\mathrm{Cl}^{-}\left(\mu \mathrm{mol} . \mathrm{L}^{-1}\right)$ & 54,0 & 0,6 & 44,9 & 0,7 \\
\hline Total Al $\left(\mu \mathrm{mol} . \mathrm{L}^{-1}\right)$ & 2,1 & 0,4 & 28,4 & 1,0 \\
\hline
\end{tabular}

589

590

591

592

593

594

595

596

597

598

599 
600 Table 3. Summary of the 2-way analysis of variance. F : F ratio ; p : probability; d.f. : degrees

601 of freedom.

\begin{tabular}{|c|c|c|c|c|c|c|c|c|c|}
\hline & \multicolumn{3}{|c|}{ [Cl] haemolymph } & \multicolumn{3}{|c|}{$\left[\mathrm{Na}^{+}\right]$haemolymph } & \multicolumn{3}{|c|}{ Survival } \\
\hline & d.f. & $\mathrm{F}$ & $p$ & d.f. & $\mathrm{F}$ & $p$ & d.f. & $F$ & $\mathrm{p}$ \\
\hline \multicolumn{10}{|l|}{ a) Gammarus fossarum } \\
\hline Factor a (Stream) & 1 & 79,4 & $<10^{-3}$ & 1 & 99,3 & $<10^{-3}$ & 1 & 228,3 & $<10^{-3}$ \\
\hline Factor b (Exposure time) & 3 & 18,1 & $<10^{-3}$ & 3 & 20,1 & $<10^{-3}$ & 3 & 54,2 & $<10^{-3}$ \\
\hline Interaction & 3 & 10,7 & $<10^{-3}$ & 3 & 14,2 & $<10^{-3}$ & 3 & 47,2 & $<10^{-3}$ \\
\hline \multicolumn{10}{|l|}{ b) Hydropsyche pellucidula } \\
\hline Factor a (Stream) & 1 & 32,3 & $<10^{-3}$ & 1 & 28,9 & $<10^{-3}$ & 1 & 33,0 & $<10^{-3}$ \\
\hline Factor b (Exposure time) & 3 & 12,9 & $<10^{-3}$ & 3 & 9,3 & $<10^{-3}$ & 3 & 6,7 & $<5^{*} 10^{-5}$ \\
\hline Interaction & 3 & 6,8 & $<10^{-3}$ & 3 & 5,9 & $<5^{*} 10^{-5}$ & 3 & 3,9 & $<10^{-2}$ \\
\hline \multicolumn{10}{|l|}{ c) Dinocras cephalotes } \\
\hline Factor a (Stream) & 1 & 5,4 & $<10^{-2}$ & 1 & 3,0 & n.s. & 1 & 16,8 & $<10^{-3}$ \\
\hline Factor b (Exposure time) & 3 & 4,9 & $<5^{*} 10^{-5}$ & 3 & 3,7 & $<10^{-2}$ & 3 & 3,5 & $<10^{-2}$ \\
\hline Interaction & 3 & 2,0 & n.s. & 3 & 0,8 & n.s. & 3 & 3,5 & $<10^{-2}$ \\
\hline
\end{tabular}

602 